УДК $371.13: 373$

DOI:

Наталія Гречаник, кандидат педагогічних наук, дочент кафедри педагогіки і психології початкової освіти, докторант Глухівського національного педагогічного університету імені Олександра Довженка

\title{
КУЛЬТУРОЛОГІЧНИЙ ПІДХІД ПІДГОТОВКИ МАЙБУТНІХ УЧИТЕЛІВ ПОЧАТКОВОЇ ШКОЛИ В ОСВІТНЬОМУ ПРОСТОРІ ВИЩОЇ ШКОЛИ
}

Стаття присвячена актуальній в умовах сучасної освітньої моделі у вищих закладах освіти проблемі культурологічної підготовки вчителів початкової школи й аналізу сутнісних характеристик понятійнокатегоріального апарату, який ї̈ забезпечує. Культурологічний підхід ие вимір освітньої системи, изо відображає не стільки сочіальну стратифікацію й структуру суспільного виробництва, скільки культурний простір,щуо відповідає його формам у своӥх базових змістовно-структурних параметрах. Зазначено, щзо освіта є спеціалізованим способом трансляції й освоєння культурного досвіду, вона соціальний інститут із функцією відтворення поведінки й свідомості людей, інакще кажучи, культурного відтворення людини або відтворення культури людини в суспільстві.

Ключові слова: виховання; гармонія; культурологічна підготовка; майбутній учитель; освіта;навчання; парадигма; проиес; суспільство.

תim. 7.

Nataliya Hrechanyk, Ph.D.(Pedagogy), Associate Professor of the Pedagogy and Psychology of Elementary Education Department, Doctoral Student Hlukhiv Oleksander Dovzhenko National Pedagogical University

\section{CULTURAL APPROACH TO PREPARATION OF FUTURE PRIMARY SCHOOL TEACHERS IN THE HIGHER EDUCATION SPACE}

The theoretical structure of culturogical training of future teachers develops in a direction to the process of humanization of consciousness and activity of future teachers, which is relevant for the whole modern world and future post-industrial society. Today it is described as a system of personal development, which is capable of harmonizing the relationship between a person and the state, justifying the very presence of man in nature and culture, overcoming the spiritual, economic and environmental crisis and dangerous lag of the spiritual development of mankind behind its technical progress. The peculiarity of culturological training is that it is conditioned and oriented not so much to the order of the state and the market, but directly to culture.

By mastering its spiritual and material wealth, an individual becomes a capable person to consciously building a living environment, reasonable relationships with nature and so on. The concept of culturological training offers to see higher educational institutions as an instrument and condition of liberation of the individual from the repressive pressure of the state, official ideology, market needs. Culturogical training provides an opportunity to develop its program of education and upbringing of personality as the path of mankind, the path that passes in the array of national and universal creative experience, to be mastered from the standpoint of culture. At the same time, the socialization of the individual is not reduced to adaptation, but implies the development of the ability to adequately interpret the sociocultural situation and to act in it with dignity and responsibility.

The implementation of the cultural creativity function offers the selection of culture-type content and reconstruction of cultural standards and norms in educational structures, designs visual elements of cultural environment, culture-type way of life of people in society. A prerequisite for this is the integration of education into culture and vice versa. It is possible to preserve culture only through a person. For this purpose, education, and, in particular, above, must lay the mechanism of cultural identification in it.

Keywords: an education; harmony; culturogical preparation; a future teacher; upbringing, learning; paradigm; a process; society.

Постановка проблеми. Оновлення всіх аспектів життєдіяльності суспільства й реалізація завдань Національної доктрини розвитку освіти України в XXI ст., державної національної програми “Освіта" (Україна XXI століття), Національної стратегії розвитку освіти в Україні на 2012 - 2021 роки, однією з провідних ідей якої $\epsilon$ “виховання людини інноваційного типу мислення й культури” $[6,86]$ визначають пріоритетність формування особистості нового типу. Освіта процес і результат цілеспрямовано-організованого інформаційного окультурення суб' єктів діяльності 3 метою забезпечення відтворення, підтримки й безперервного розвитку людського життя. Не випадково освіта представляє собою єдність навчання й виховання, причому значення кожної 3 


\section{КУЛЬТУРОЛОГІЧНИЙ ПДХІДПДГОТОВКИ МАЙБУТНІХ УЧИТЕЛІВ ПОЧАТКОВОЇ ШКОЛИ В ОСВІТНЬОМУ ПРОСТОРІ ВИЩОЇ ШКОЛИ}

цих функцій історично змінювалося відповідно до рівня розвитку суспільства та його соціальної структури. Розгляд освіти з точки зору соціального інституту дозволяє більш виразно розмежувати зміни в ньому, що спричинені внутрішніми закономірностями його розвитку як специфічного інституту, зокрема, через виконання основної суспільної функції відтворення культури.

Чим викликана актуальність проблеми привнесення культурологічного компонента в освіту? На наш погляд, це, перш за все, наявність існуючих протиріч між потребою формуванням загальнокультурної компетентності школярів і студентів і недостатнім рівнем розробки теоретико-методологічного й технологічного забезпечення зазначеного процесу в педагогічній науці; потенціалом гуманітарних дисциплін для вдосконалення навчально-виховного процесу й недостатнім його використанням викладачами вищих закладів освіти; зростаючими культурологічними освітніми запитами й підготовкою майбутніх учителів до розкриття загальнокультурного контексту предметів, що викладаються в початковій школі $[7,2]$.

Поряд із цим, головна причина, на наш погляд, у тому, що людина виявилась непристосованою до нового темпу розвитку цивілізації. По-перше, практично повністю ліквідується зв'язок між наукою, пізнанням навколишнього світу, його світосприйняттям і будь-якою духовністю. Треба розглядати сучасні гуманізаційні можливості освіти, усвідомлюючи, що саме духовне, гуманістичне, людське й людяне $є$ сутнісною основою в історії еволюції цивілізації, а відображення цих цінностей у системі природничо-наукового, фізико-математичного й соціогуманітарного знання є засадою освітнього й педагогічного впливу на формування особистості [1, 46]. По-друге, методика пізнавального процесу звужується до педантичного емпіризму й чисто розумових узагальнень відомого матеріалу. По-третє, наукова діяльність повністю вивільняється від будь-яких зв'язків з практикою, корисливість або безкорисливість мотивів ученого не мають ніякого відношення до плідності його досліджень. I почетверте, наука відкривається для будь-кого, хто володіє завзятістю й старанністю.

Зростання матеріальних потреб сучасної людини породило гігантську індустрію побуту. Ресурси випивають, вирубуються, виловлюються, знищуються з жахливою швидкістю. Енергетика стала обов'язковою супутницею будь-якої розвиненої країни. Вона ж послужила причиною величезного числа катастроф, які цілком можуть закінчитися і вселенською катастрофою. Невтомна праця кращих учених виявилася не в змозі вберегти світ від СНІДу, масових хвороб, алкоголізму й наркоманії. Усе це свідчить про зовсім незадовільний стан культурологічного розвитку суспільства, освітньої філософії й індустріально-технологічної практики. Суспільство фактично змирилося з існуванням “одновимірної” людини із вузьким світобаченням. Шляхи успішного подолання цієї кризової ситуації, на загальне переконання, значною мірою визначаються й ще в більшій мірі будуть визначатися в майбутньому, перш за все, рівнем освіченості й культури суспільства $[2,4]$.

Аналіз останніх досліджень і публікацій. Одну із перших моделей культуровідповідної професійної підготовки розробив Ю. Пассов, який запропонував замість традиційної освітньої парадигми (загальної і професійної), що сконцентрована навколо знань, увести культурологічну, за якої учитель $є$ носієм культури. Учені одностайні в тому, що набуття комунікативної компетентності неможливе без володіння країнознавчими та культурологічними знаннями (В. Бадер, Н. Бориско, А. Брагіна, В. Дороз, Г. Слизарова, О. Мацюк, О. Миролюбов, С. Ніколаєва, А. Ніколенко, Ю. Пассов, С. Пілішек, В. Топалов, В. Сафонова).

У ряді робіт російських учених (О. Бондаревська, Є. Білозерцев, В. Краєвський, Л. Разбегаєв, В. Сєріков, І. Якиманська) зроблена спроба аналізу та окреслення напрямів реалізації оновленої парадигми освітнього процесу, що забезпечить культурологічну спрямованість професійної підготовки майбутнього вчителя.

На сьогодні є певні вагомі результати щодо вирішення питання у взаємозв'язку вивчення культури й мови (переважно іноземної) у середній і вищій школі. Проте потребує фундаментального дослідження проблема культурологічної підготовки майбутніх фахівців початкової освіти. Ефективність ¥ї формування 3 позицій культурологічної компетентності майбутніх учителів-початківців сприятиме уточненню її суті.

Мета статті - визначення й теоретичне осмислення проблем культурогічного підходу підготовки майбутніх учителів початкової школи у системі вищої педагогічної освіти.

Виклад основного матеріалу. 3 кожним днем стає більш очевидним, що вся система знань про світ, людину й суспільство має бути кардинально переглянута з урахуванням зміни сучасних вимог як до утворення, так і до духовної спадщини української нації, її самобутності, православної культури. У світлі культурологічного 
підходу епіцентром освіти є людина як вільна активна індивідуальність, здатна до особистісної самодетермінації в спілкуванні та співпраці 3 іншими людьми, сама з собою і культурою [4]. Існує ще одна група причин, які вказують на необхідність посилення культурологічного компонента в підготовці вчителя. Це зумовлено тим, що глобальний розвиток соціуму в останні десятиліття все більш активно в освітньому просторі визначає пріоритет людської особистості.

Сучасні вимоги формування освіченої особистості вимагають вирішення ряду взаємопов'язаних завдань. Перш за все, це стосується гармонізації відносин людини 3 природою через ознайомлення із сучасною картиною Всесвіту, усвідомлення свого місця в природі, що дасть можливість на цьому підгрунті вирішити проблеми екології та ноосфери. Наступне. Необхідно виходити з того, що людина живе в соціумі, $і$ для її послідовної раціональної соціалізації необхідна реалізація процесу інкультурації в нього через освоєння історії, норм права, культурології, філософії. Третє завдання. Людина сучасної доби живе в умовах насиченого інформаційного простору, і завдання підготовки майбутнього фахівця у площині культурологічного підходу навчити жити останнього в ньому, створити передумови для формування потреби в безперервній самоосвіті. I наостанок. Особистість повинна перебувати в консонансі сама $з$ собою, що вимагає певних знань у галузі психології, фізіології, у сфері літератури й мистецтва. Цей процес повинен стати інтеріоризаційним для особистості.

Спостерігаючи й аналізуючи сучасну соціокультурну ситуацію в усіх аспектах людської практичної діяльності, можна побачити, що сама ця ситуація ніби підказує напрямок розвитку освітньої системи. Культуротворча модель культурологічної освіти (А.П. Валицька, І.А.Зязюн, М.П. Лещенко та ін.) виходить із думки про те, що освітня система відбиває не соціальну стратифікацію й не структуру суспільного виробництва, а простір культури, відповідаючи його змісту й формам у своїх основних змістовноструктурних параметрах. Культура розглядається як людський спосіб життєдіяльності, духовноматеріальне середовище перебування людини, освіта - як процес становлення творчої особистості в природо-соціокультурному середовищі $[5,84]$. На сьогодні вже затребувані люди, що вміють швидко пристосовуватися до будь-яких змін, гнучкі, здатні працювати більше, ніж в одній професійній позиції, (у тому числі й у ролі керівника), допитливі, які прагнуть з'ясувати стан існуючих речей і впливати на те, що відбувається, здатні тримати себе в руках, мати холодний розум в умовах невизначеності (навіть в умовах абсолютної незрозумілості), здатні володіти досвідом у кількох галузях практичної діяльності, а не тільки в окремій спеціальності, сприйнятливі до новизни й до вмілого використання іiї у своєму житті, здатні здійснювати трансфер ідеї з однієї області знання в іншу, комбінувати ідеї, синтезувати на основі комбінації нові думки [3, 99]. Таким чином, повністю зміниться матриця підготовки майбутнього вчителя початкової школи, що у свою чергу обумовлює зміни в його підготовці, орієнтуючи цей процес на розуміння ним сучасної соціокультурної ситуації, знання основ філософії освіти, історії культури, тобто актуальною стає проблема побудови системи культурологічної підготовки майбутнього вчителя.

Віддаючи пріоритет культурологічній парадигмі в системі вищої освіти, ми аж ніяк не применшуємо значення парадигми знаннєвоорієнтованої. Уважаємо, що вони відрізняються одна від одної лише за місцем, що відводиться в їхніх кордонах особистості: або вона є засобом, або вона $є$ метою. Разом з тим, у реальності вони виступають не як антиподи, а як два рівні, аспекти освоєння світу людиною. Культурологічний характер освіти постає як ціннісний, мотиваційносмисловий, такий, що усвідомлює людську діяльність в ії̈ призначенні, у той час як знаннєву можна розглядати як інструментальну, змістовну, на платформі якої здійснюються інформаційнопізнавальні функції.

Культурологічний підхід педагогічної освіти, на наш погляд грунтується на наступних принципах: - пізнання основ вітчизняної й світової культури;

- прагнення особистості до саморозвитку й самоосвіти в культурі;

- здатність майбутнього фахівця до самовизначення в культурному просторі;

- орієнтація на національну культуру в навчанні й вихованні;

- варіативність взаємного співробітництва викладачів і студентів у культурологічній підготовці майбутніх учителів;

- гуманізація освіти, що передбачає орієнтацію усіх ланок навчального процесу на особистість студента;

- гуманітаризація освіти, суть якої у відмові від технократичного підходу до процесу підготовки педагогів, психологізація всього комплексу отримуваних ними знань, надання їм культурно-значущого сенсу, формування в майбутніх учителів системного гуманітарного 


\section{КУЛЬТУРОЛОГІЧНИЙ ПІДХІДПІГОТОВКИ МАЙБУТНІХ УЧИТЕЛІВ ПОЧАТКОВОЇ ШКОЛИ В ОСВІТНЬОМУ ПРОСТОРІ ВИЩОЇ ШКОЛИ}

мислення, що базується на загальнолюдських та загальнокультурних цінностях;

- багатовекторність самого процесу навчання, тобто можливість вибору професійно-освітніх програм з урахуванням особистісних здібностей та схильностей студента;

- надання процесу педагогічної освіти культуровідповідності, фундаментальності, тобто оволодіння майбутніми фахівцями інваріантним сегментом знань, що складають базис у творчому розвитку особистості за умов сучасного мінливого світу;

- цілісність фундаментальної, предметної й психолого-педагогічної підготовки;

- гнучкість навчання, що здатне реагувати на зміну соціальних викликів і процесів, потреб ринку праці, формування на цій основі фахівців, здатних до володіння професійною мобільністю;

- безперервність освіти, тобто створення й розвиток системи ієрархічно взаємопов'язаних професійно-освітніх програм, (включаючи програми підвищення кваліфікації та перепідготовки кадрів);

- аналоговість освіти, тобто відповідність ії державним стандартам, принципам національної культури, ментальності соціуму, міжнародним вимогам.

Людина формується завдяки розпредмечуванню втілених у культурі сутнісних людських сил й одночасно уособлює себе в нових об'єктах культури. Саме подвійність такого процесу й лежить в основі освіти, тому що завдяки йому розкривається механізм створення людиною культури, відтворення й змінення іiі і навпаки. Функціонування цього дає змогу не тільки виявити міцний зв' язок освітнього й культурного феномену, а й диктує необхідність особливої акцентуації уваги на дієвій ролі людини, яка з'являється під час знаходження власного образу. Культурологічна підготовка майбутніх фахівців у цьому контекстному підході розглядається 3 позицій процесу й результату освоєння людиною системи понять у різних типах історичних, регіональних культур і $є$ запорукою самовизначення особистості в культурно-освітньому просторі.

Культурологічна компетентність майбутнього вчителя початкової школи передбачає, на наш погляд, наявність таких основних компонентів:

- створення моделі культурологічного розвитку особистості майбутнього вчителя;

- високовалідні й надійні засоби індивідуальної діагностики й самоконтролю особистості;

-упровадження спеціальнихзасобів культурологічного розвитку й саморозвитку особистості;

- ієрархічну побудову всіх існуючих методів навчання, нових цінностей в аспекті досягнення культурологічних цілей й особистісного розвитку майбутніх учителів.

Домінуючою лінією культурологічного підходу $\epsilon$ культурологічна підготовка, зміст якої передбачає, крім загальнонаукової і предметної, наступне: діалогічність мислення, здібності до реалізації педагогічного інструментарію, здійснення аналізу педагогічних ситуацій, проектування й планування навчально-виховних процесів, спроможність організації міжособистісних і групових взаємодій дітей, формування неподільної системи знань про людину як суб'єкта життєдіяльності, що розвивається, індивідуальності, а також усебічного розуміння змісту, структури освітніх процесів і технологій, що їх реалізують.

Отже підсумовуючи, зазначимо, що завданнями культурологічної підготовки майбутніх фахівців у вищій ланці освіти є:

- генерація професійно-педагогічної культури особистості майбутнього вчителя початкової школи;

- прагнення до розвитку культуротворчих форм і методів навчання й засобів виховання, що мають високий рівень професійної кваліфікації, спроможність до системного аналізу проблемного поля сучасного життя, культурних надбань, цивілізації, прагнення людини знайти саму себе, свій людський образ;

- удосконалення форм і методів підготовки вчителів, спрямованих на оволодіння різними технологіями навчання й виховання, діалог культур, суб'єкт-суб'єктні стосунки, рольові й ділові ігри в процесі навчання, спрямовані на оптимізацію комунікативної взаємодії педагога, а також нових педагогічних форм і методів навчання.

Висновки. Людство досягло в своєму розвитку критичного стану, при якому існуюча освіта виявляється нездатною забезпечити вирішення глобальних проблем. Як конкретне рішення пропонується концепція навчання нового типу інноваційного, а сама освіта має орієнтуватися на формування культури особистості, на саму особу, тобто бути особистісно орієнтованою освітою. Уведення культурологічної підготовки в систему освіти повинно стати необхідним кроком на шляху до збереження своїх культурних коренів, входження української культури в родину загальнолюдської культури. Це стосується масштабу введення культурологічної підготовки в освіту школярів і студентів. Так, якщо йдеться, наприклад, про музику або архітектуру як основні, профілюючі предмети, то варто вивчати їх як частину цілого 

В ОСВІТНЬОМУ ПРОСТОРІ ВИЩОЇ ШКОЛИ

- як особливі сфери людської творчості, що становлять частину культурної діяльності людства взагалі й національної культури зокрема. Подібне культурологічне переломлення профілюючих предметів дозволить не зосереджувати свідомість студентів лише на вузькопрофесійних особливостях і цілях своєї майбутньої професії, але розширить іiі до загальнокультурних меж. Це й буде властивою культурологічною підготовкою, оскільки фахівець-культуролог навіть за наявності вузької спеціалізації, наприклад, мистецтвознавчої, зобов'язаний розуміти, що мистецтво є лише частиною культурної творчості людей, що співвідноситься по своїх архетипічних зразках $з$ іншими сферами творчості, починаючи від сільського господарства й закінчуючи космічними технологіями. У цьому випадку культурологічна підготовка виконає своє основне завдання:

1) надасть засоби й можливість гармонічної i безболісної соціалізації дитини, або підлітка через правильне сприйняття культурних цінностей і традицій свого народу;

2) дозволить зрозуміти інші культури й пояснити їм особливості своєї власної, тобто ввійти як рівноправний член у родину культур і народів людства $[5,86]$.

Таким чином, культурологічний потенціал педагогічної освіти в нашому розумінні означає здійснення процесу освіти й розвитку особистості вчителя через призму поняття культури. Цей процес здійснюється вособливому культуровідповідному середовищі, що наповнений людськими смислами й дає можливість особистості вільно проявляти свою індивідуальність, культурного саморозвитку й самовизначення у світі культурних цінностей. Аналіз культурологічного підходу до освіти, на наш погляд, грунтується на наступних концептуальних положеннях:

- освіта може врятувати культуру, якщо в центрі освітнього та виховного процесу буде стояти людина, а не знання, як було до того;

- олюднити освіту значить включити в коло іiі проблем людину як основну цінність;

- як діалогу минулих, нинішніх і майбутніх культур.

\section{ЛІТЕРАТУРА}

1. Касьянов Д. Філософські засади гуманізації освітнього простору в умовах нанотехнологічного розвитку суспільства. Вища освіта Украӥни. 2012. № 2. С. 43-49.

2. Кинелев В. Г. Образование для информационного общества. URL: http://oaji.net/articles/2017/7741506921196.pdf C. 3-15 (дата звернення: 02.01.2020).
3. Кондрусева В. Н. Антропологический кризис в контексте философии образования. Ученые записки Таврического национального университета им. В.И. Вернадского. Серия “Философия. Культурология. Политология. Социология”. Том 34 (63). 2011. № 3 4. С. 95102.

4. Культурологическая парадигма образования в концепции академика И. Зязюна URL://zn.ua/ EDUCATION/kulturologicheskaya-paradigmaobrazovaniya-v-koncepcii-akademika-i-zyazyuna.html (дата звернення 03.01.2020).

5. Левенець М. В. Моделювання культурологічної освіти у сучасних вищих навчальних закладах. Вісник Національної академії керівних кадрів культури і мистецтв. 2013. № 2. С. 83-86.

6. Національна стратегія розвитку освіти в Україні на 2012-2021 роки. Вищза школа. 2013. № 2. С. 86-96.

7. Шпиталевська Г. Р. Підготовка майбутніх учителів початкових класів до формування у молодших школярів загальнокультурної компетентності: автореф. дис. ... канд. пед. наук: 13.00.04. Республіканський вищий навчальний заклад "Кримський гуманітарний університет". Ялта, 2013. 20 c.

\section{REFERENCES}

1. Kasianov, D. (2012). Filosofski zasady humanizatsii osvitnoho prostoru $\mathrm{v}$ umovakh nanotekhnolohichnoho rozvytku suspilstva. [Philosophical foundations of humanization of educational space in the conditions of nanotechnological development of society]. Ukrainian higher school. No. 2. pp. 43-49. [in Ukrainian].

2. Kynelev, V.H. Obrazovanye dlia ynformatsyonnoho obshchestva. [Education for the Information Society]. Available at: http://oaji.net/articles/2017/7741506921196.pdf pp. 3 15. (accessed 02. Jan. 2020). [in Russian].

3. Kondruseva,V. N. (2011). Antropolohycheskyi kryzys v kontekste fylosofyy obrazovanyia [Anthropological crisis in the context of the philosophy of education]. Scientists notes from the Vernadsky Tauride National University. Series "Philosophy. Culturology. Political science. Sociology” series. Vol. 34 (63). No. 3 4. pp. 95 102. [in Ukrainian].

4. Kulturolohycheskaia paradyhma obrazovanyia v kontseptsyy akademyka Y. Ziaziuna [Cultural paradigm of education in the concept of academician I. Zyazyun]. Available at: https://zn.ua/EDUCATION/ kulturologicheskaya-paradigma-obrazovaniya-vkoncepcii-akademika-i-zyazyuna-.html (accessed 03. Jan. 2020). [in Ukrainian].

5.Levenets,M.V.(2013).Modeliuvanniakulturolohichnoi 


\section{КОНЦЕПЦІЯ ФОРМУВАННЯ ГОТОВНОСТІ МАГІСТРІВ ДО ЗАБЕЗПЕЧЕННЯ ЯКОСТІ ОСВІТНЬОГО ПРОЦЕСУ В ЗАКЛАДІ ДОШКІЛЬНОЇ ОСВІТИ}

osvity u suchasnykh vyshchykh navchalnykh zakladakh [Modeling of culturological education in modern higher education institutions]. Herald of the National Academy of Leaders of Culture and Arts. No. 2. pp. 8386. [in Ukrainian].

6. Natsionalna stratehiia rozvytku osvity v Ukraini na 2012-2021 roky [National Strategy for the Development of Education in Ukraine for 2012-
2021]. Higher School. No. 2. pp. 86-96. [in Ukrainian].

7. Shpytalevska, H. R. (2013). Pidhotovka maibutnikh uchyteliv pochatkovykh klasiv do formuvannia u molodshykh shkoliariv zahalnokulturnoi kompetentnosti [Preparing future primary school teachers to develop general cultural competence among younger students]. Extended abstract of candidate's thesis. Yalta. 20 p. [in Ukrainian].

Стаття надійшла до редакції 23.12.2019

УДК 378. 0011.-051:373.2

DOI:

Людмила Загородня, кандидат педагогічних наук, доиент кафедри дошкільної педагогіки і психологї

Глухівського національного педагогічного університету імені Олександра Довженка

\section{КОНЦЕПЦІЯ ФОРМУ ВАННЯ ГОТОВНОСТІ МАГІСТРІВ ДО ЗАБЕЗПЕЧЕННЯ ЯКОСТІ ОСВІТНЬОГО ПРОЦЕСУ В ЗАКЛАДІ ДОШКІЛЬНОЇ ОСВІТИ}

У статті представлено концеецію формування готовності магістрів до забезпечення якості освітнього прочесу в закладі дошкільної освіти. Визначено мету, ідею й основні положення концепції. Висвітлено методологічний, теоретичний і технологічний концепти системи підготовки магістрів до забезпечення якості освітнього процесу в закладі доикільної освіти.

Ключові слова: концепція; готовність магістрів до забезпечення якості освітнього прочесу в закладі дошкільної освіти; методологічний концепт; теоретичний концеетт; технологічний концепт.

Jim. 12.

Lyudmyla Zahorodnya, Ph.D.(Pedagogy), Associate Professor of the Pedagogy and Psychology Department, Hlukhiv Oleksandr Dovzhenko National Pedagogical University

\section{THE CONCEPT OF FORMING THEMASTERS' READINESSFOR PROVIDING THEQUALITYOFEDUCATIONALPROCESSINPRESCHOOLEDUCATIONESTABLISHMENTS}

The primary task of the Ukrainian education system is to provide the educational services recipient with qualitative education. The effectiveness of preschool education depends on the qualitative Masters' training, in particular their readiness to ensure the quality of the educational process in a preschool institution.

In the article the concept of forming the masters' readiness for educational process quality assurance in a preschool education institution, structured by methodological, theoretical and technological concepts is presented; its purpose, idea, tasks, main principles and conditions are defined.

According to the methodological bases of developing the content of Masters' training to educational process quality assurance in a preschool education institution, the theoretical and methodological principles which reveal the orientation of preschool education Masters' training and the higher education content at four methodological levels - philosophical, general scientific, specific scientific and methodical - are crucial for its improvement.

In accordance with the theoretical concept the basic definitions, regularities and principles of training are defined. It allows us to investigate the interrelated components (purpose, methodological, organizational, structural and content, process and technological, result and evaluation) and components of the model of Masters ' professional training system for quality assurance of educational process in a preschool education institution.

The core of the author's concept is the regularities and principles that are taken into account during the implementing the effective activity of the Masters' system training to ensure the quality of the educational process in a preschool education institution.

According to the technological concept, it is possible to develop, implement and experimentally check the system of Masters' training for quality assurance of educational process in a preschool education institution, in particular its organizational, structural and content, process and technological, result and evaluation components.

Keywords: a concept; Master's readiness to ensure the quality of the educational process in a preschool education institution; a methodological concept; a theoretical concept; a technological concept.

П

остановка проблеми. Першочерговим завданням української освітньої системи забезпечення здобувачів освітніх послуг

(C)

Л. Загородня, 2020 якісною освітою. Ефективність дошкільної освіти залежить від якісної підготовки магістрів.

Аналіз основних досліджень і публікацій. 